\title{
Study on the potential change of corroded reinforced concrete in ECE with MPC-CFRP as anode
}

\author{
Yue $\mathrm{Li}^{1}$, Xiuhu Zhang ${ }^{1, *}$ and S.M.Ali S.Hejazi ${ }^{1}$ \\ ${ }^{1}$ The Key Laboratory of Urban Security and Disaster Engineering, MOE. Beijing University of Technology, 100124, China
}

\begin{abstract}
Aiming at the rust removal requirements of reinforced concrete, the MPC-CFRP composite material was used as the external anode, and the Electrochemical chloride extraction (ECE) method was used to test the polarization curve of the steel bar under different ECE current densities, and the potential changes of the steel bar at different times were analyzed. The results show that the ECE system with MPC-CFRP as the external anode has a good effect of reducing the corrosion rate and the risk of corrosion of steel bars. The current density of $3 \mathrm{~A} / \mathrm{m}^{2}$ is higher than that of $1 \mathrm{~A} / \mathrm{m}^{2}$ in dechlorination efficiency. After 28 days of ECE, the current density of $1 \mathrm{~A} / \mathrm{m}^{2}$ and $3 \mathrm{~A} / \mathrm{m}^{2}$ can re passivate the reinforcement.
\end{abstract}

\section{Introduction}

Corrosion of steel bars is the main reason that affects the durability of reinforced concrete structures [1]. Chloride corrosion is the main cause of steel corrosion [2-4]. ECE can effectively inhibit the corrosion of steel bars and improve the durability of corroded reinforced concrete structures [5]. External anode material of ECE is one of the research hotspots at present. Carmona et al. studied the effect of ECE of different anodes, and pointed out that for the isotropic structural elements, the effect of desalting with $\mathrm{Ti}-\mathrm{RuO}_{2}$ as anode and conductive mortar as anode is almost the same [6]. Yeih added carbon rod as auxiliary electrode in concrete, and used two different anode devices, radial type and layer type, to carry out electrochemical desalting. The results showed that the dechlorination effect of layer type device was slightly better than that of radial type device [7]. Saraswathy et al. compared the difference between CCPA (conductive placement paste anode) and traditional metal as ECE anode, pointed out that the cost of CCPA as anode is lower, the desalination performance is the same as that of metal anode, and it is more suitable for long-term application under the current density of $0.5 \mathrm{~A} / \mathrm{m}^{2}$ [8]. CFRP is often used to reinforce reinforced concrete structures [9]. At the same time, CFRP has excellent electrical conductivity, and its performance is still good after accelerated polarization in alkaline solution $[10,11]$.
In this paper, magnesium phosphate cement (MPC) is used as the binder to bond CFRP on the surface of corroded reinforced concrete, forming MPC-CFRP composite as the external anode of ECE. By collecting the polarization curve of steel bars in the process of electrochemical desalting, the change trend of corrosion potential and corrosion current of steel bars in the reinforced concrete columns with and without desalting was analyzed, and the influence of $1 \mathrm{~A} / \mathrm{m}^{2}$ and $3 \mathrm{~A} / \mathrm{m}^{2}$ current density on the efficiency and effect of ECE was compared.

\section{Test overview}

\subsection{Raw materials and mix proportion}

The raw materials for manufacturing corroded reinforced concrete columns include: P.O42.5 Portland cement; $5 \sim 25 \mathrm{~mm}$ continuous graded crushed stone, with apparent density of $2650 \mathrm{~kg} / \mathrm{m}^{3}$; river sand with fineness modulus of 2.56; polycarboxylic acid water reducer with water reduction rate of $31 \%$. There are two types of reinforcement in the column: HRB400 and HPB300. The concrete mix is shown in Table 1. In order to accelerate the corrosion of reinforcement, the concrete is mixed with $3 \%$ sodium chloride of cement mass fraction to discuss the effect of ECE.

Table 1. Concrete mix ratio $(\mathrm{kg} / \mathrm{m} 3)$ and mechanical properties.

\begin{tabular}{cccccccc}
\hline Cement & Sand & Stone & Water & $\begin{array}{c}\text { Water } \\
\text { reducer }\end{array}$ & $\mathrm{NaCl}$ & $\begin{array}{c}\text { Compressive } \\
\text { strength of 28 } \\
\text { days (MPa) }\end{array}$ & $\begin{array}{c}\text { Slump } \\
(\mathrm{mm})\end{array}$ \\
\hline 325 & 662 & 1228 & 185 & 0.65 & 9.75 & 36 & 180 \\
\hline
\end{tabular}

\footnotetext{
* Corresponding author: 952233638@qq.com
} 
Table 2. Mix proportion and mechanical properties of MPC cement.

\begin{tabular}{ccccccc}
\hline \multirow{2}{*}{$\mathrm{P} / \mathrm{M}$} & \multirow{2}{*}{$\mathrm{B} / \mathrm{M}$} & $\mathrm{W} / \mathrm{C}$ & \multicolumn{4}{c}{ Compressive strength (MPa) } \\
\cline { 4 - 7 } & & & $3 \mathrm{~h}$ & $1 \mathrm{~d}$ & $7 \mathrm{~d}$ & $28 \mathrm{~d}$ \\
\hline $1 / 4.5$ & 0.05 & 0.14 & 22 & 32 & 41 & 65 \\
\hline
\end{tabular}

The materials used to prepare the ECE anode MPC-CFRP include calcined $\mathrm{MgO}(\mathrm{M})$ at $1600^{\circ} \mathrm{C}$, chemically pure $\mathrm{KH}_{2} \mathrm{PO}_{4}(\mathrm{P})$, retarder boric acid $\mathrm{B}$. The mix design and related performance of MPC are shown in Table 2. The thickness of CFRP is $0.19 \mathrm{~mm}$, the ultimate tensile strength and fracture strain are $4200 \mathrm{Mpa}$ and $2 \%$, respectively.

\subsection{RC component manufacturing}

Fabricate reinforced concrete column $(750 \mathrm{~mm}$ in height $\times 200 \mathrm{~mm}$ in diameter), $25 \mathrm{~mm}$ in concrete protective layer, and the upper end of longitudinal bar extends out of the concrete surface by $150 \mathrm{~mm}$. The geometric dimension and reinforcement of the component are shown in Figure 1.

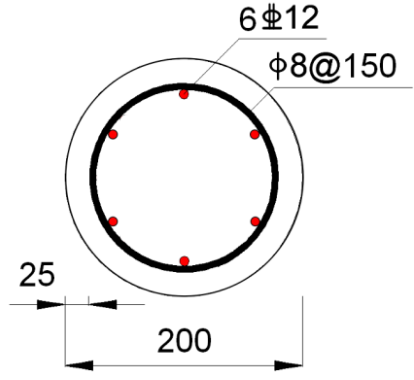

Figure 1. Design dimension of reinforced concretetest piece.

Table 3. ECE design.

\begin{tabular}{ccc}
\hline Number & $\begin{array}{c}\text { Whether there is } \\
\text { electric acceleration } \\
\text { corrosion before } \\
\text { ECE }\end{array}$ & $\begin{array}{c}\text { Extraction age } \\
\text { and current } \\
\text { density of ECE }\end{array}$ \\
\hline A0 & No & No ECE \\
A & Yes & No ECE \\
A-C1 & Yes & 28days, $1 \mathrm{~A} / \mathrm{m}^{2}$ \\
A-C3 & Yes & 28days, $3 \mathrm{~A} / \mathrm{m}^{2}$ \\
\hline
\end{tabular}

\subsection{ECE test design and method}

Before ECE, the reinforced concrete column was electrified for 24 days by constant current method to accelerate the corrosion of steel bars; then, MPC was painted on the surface of corroded reinforced concrete column and CFRP was pasted as the anode of ECE and the column longitudinal bar as the cathode. After 7 days of curing, it was immersed in saturated $\mathrm{Ca}(\mathrm{OH})_{2}$ solution, and ECE was carried out by DC stabilized voltage source. The electrolyte was changed every 7 days, and the time of ECE was 28 days. The ECE test design and apparatus are shown in Table 3 and Figure 2.

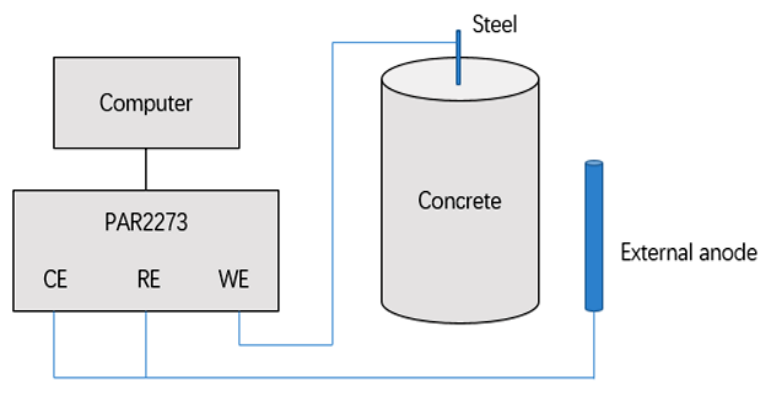

(a) ECE test schematic

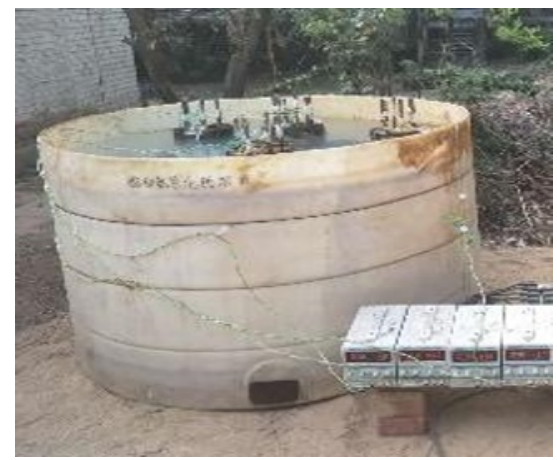

(b) ECE experimental device

Figure 2. ECE test schematic diagram and actual test device.

\section{Results and discussion}

\subsection{Polarization curve analysis of reinforced concrete specimens}

The polarization curve of reinforced concrete column is tested every 7 days after ECE starts, and the polarization curve of reinforcement is shown in Figure 3 . The change of corrosion potential $\left(\mathrm{E}_{\text {corr }}\right)$ and corrosion current $\left(\mathrm{I}_{\text {corr }}\right)$ with time in the process of ECE can be calculated from the polarization curve of reinforcement, as shown in Table 4.

It can be seen from Figure 3 and Table 4 that with the increase of test time, the corrosion potential of the reinforced concrete column without ECE treatment in the test piece shifted to the negative pole and the corrosion current moved to the positive pole by a small margin, in which the corrosion potential of $\mathrm{A} 0$ and a decreased from $-234.57 \mathrm{mV}$ and $-609.73 \mathrm{mV}$ to $-313.53 \mathrm{mV}$ and -750.63 $\mathrm{mV}$ respectively, while the corrosion current increased from $0.32 \mu \mathrm{A} / \mathrm{cm}^{2}$ and $10.48 \mu \mathrm{A} / \mathrm{cm}^{2}$ to $2.25 \mu \mathrm{A} / \mathrm{cm}^{2}$ and $16.42 \mu \mathrm{A} / \mathrm{cm}^{2}$; after ECE treatment, the corrosion potential of the reinforced concrete column first shifted to the negative pole, then shifted to the positive pole, and the corrosion current moved to the negative pole. The 


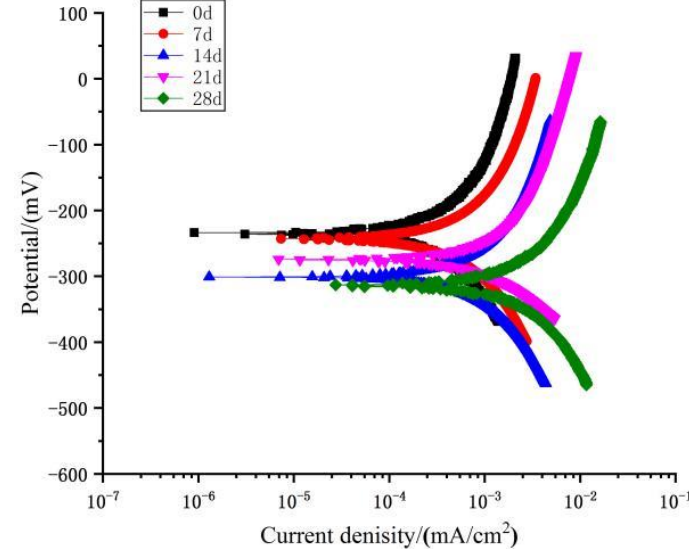

(a) A0

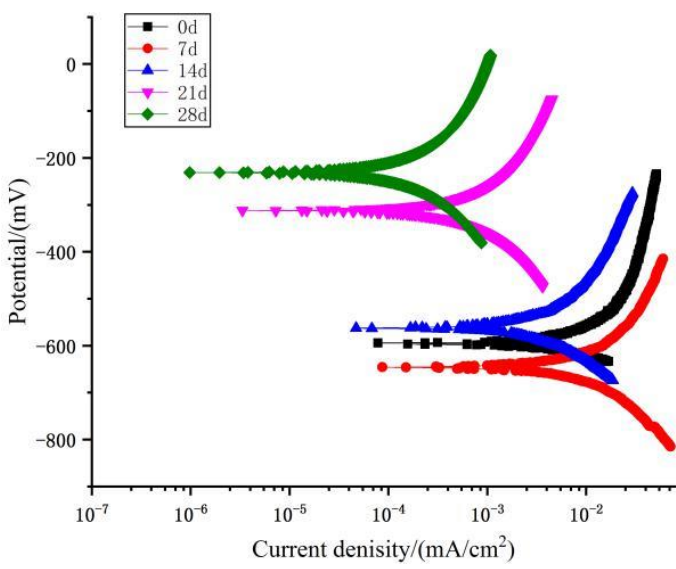

(c) A-C1

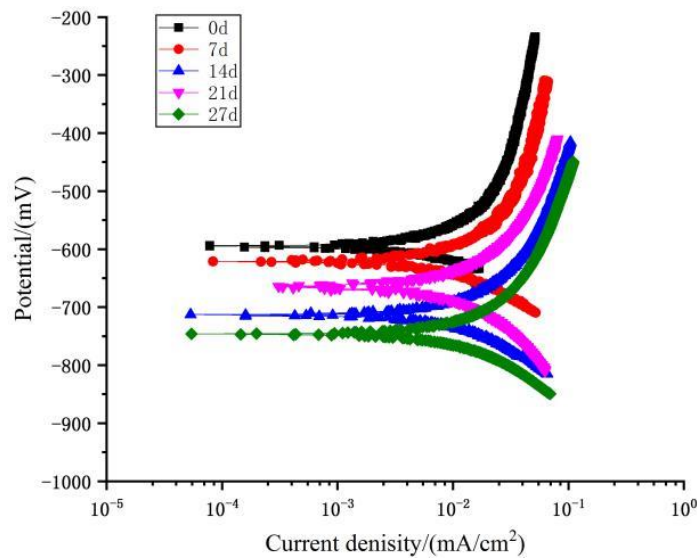

(b) A

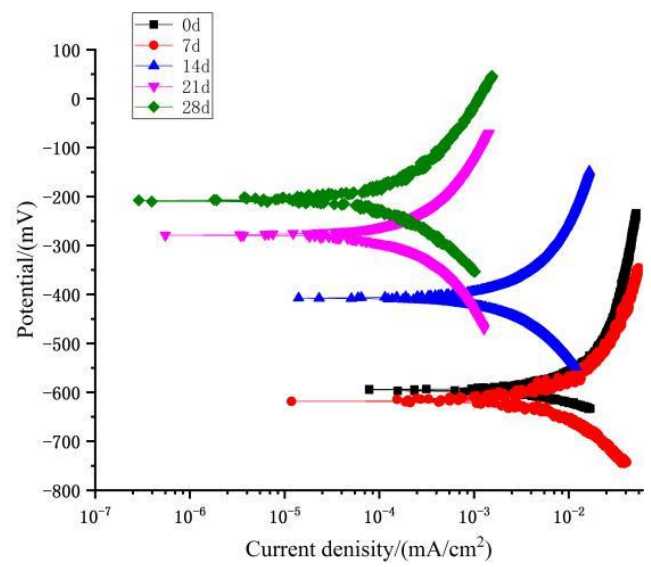

(d) A-C3

Figure 3. Tafel curves of steel bar.

Table 4. Corrosion potential and corrosion current density of rebar.

\begin{tabular}{cccccccccc}
\hline & \multicolumn{7}{c}{ Number } \\
\cline { 2 - 9 } $\mathrm{t} / \mathrm{d}$ & \multicolumn{2}{c}{$\mathrm{A} 0$} & \multicolumn{2}{c}{$\mathrm{A}$} & $\mathrm{A}-\mathrm{C} 1$ & \multicolumn{2}{c}{ A-C3 } \\
\cline { 2 - 9 } & $\begin{array}{c}\mathrm{E}_{\text {corr }} \\
(\mathrm{mV})\end{array}$ & $\begin{array}{c}\mathrm{I}_{\text {corr }} \\
\left(\mu \mathrm{A} / \mathrm{cm}^{2}\right)\end{array}$ & $\begin{array}{c}\mathrm{E}_{\text {corr }} \\
(\mathrm{mV})\end{array}$ & $\begin{array}{c}\mathrm{I}_{\text {corr }} \\
\left(\mu \mathrm{A} / \mathrm{cm}^{2}\right)\end{array}$ & $\begin{array}{c}\mathrm{E}_{\text {corr }} \\
(\mathrm{mV})\end{array}$ & $\begin{array}{c}\mathrm{I}_{\text {corr }} \\
\left(\mu \mathrm{A} / \mathrm{cm}^{2}\right)\end{array}$ & $\begin{array}{c}\mathrm{E}_{\text {corr }} \\
(\mathrm{mV})\end{array}$ & $\begin{array}{c}\mathrm{I}_{\text {corr }} \\
\left(\mu \mathrm{A} / \mathrm{cm}^{2}\right)\end{array}$ \\
\hline 0 & -234.57 & 0.32 & -609.73 & 10.48 & -609.73 & 10.48 & -609.73 & 10.48 \\
7 & -245.89 & 0.54 & -624.96 & 13.18 & -638.89 & 9.70 & -613.80 & 8.01 \\
14 & -301.28 & 0.79 & -717.12 & 13.7 & -566.32 & 3.99 & -401.65 & 2.42 \\
21 & -279.74 & 1.26 & -664.56 & 14.05 & -310.43 & 0.69 & -272.12 & 0.21 \\
28 & -313.53 & 2.25 & -750.63 & 16.42 & -230.17 & 0.17 & -205.24 & 0.11 \\
\hline
\end{tabular}

corrosion potential of $\mathrm{A}-\mathrm{C} 1$ and $\mathrm{A}-\mathrm{C} 3$ increased from $-609.73 \mathrm{mV}$ to $-230.17 \mathrm{mV}$ and $-205.24 \mathrm{mV}$ respectively, while the corrosion current decreased from $10.48 \mu \mathrm{A} / \mathrm{cm}^{2}$ to $0.17 \mu \mathrm{A} / \mathrm{cm}^{2}$ and $0.11 \mu \mathrm{A} / \mathrm{cm}^{2}$ respectively.

The corrosion current and corrosion potential of reinforced concrete columns A-C1 and A-C3 after electrochemical desalting for 28 days were lower than those of naturally rusted reinforced concrete columns, indicating that the ECE system of MPC-CFRP as an external anode has a good electrochemical dechlorination effect.

\subsection{Influence of ECE current density on corrosion rate and corrosion risk of specimens}

Figure 4 shows the change of corrosion current and corrosion potential of longitudinal bars in the test piece. The corrosion rate and corrosion risk of the specimens A0 always increased slowly, and that of sample A1 without ECE increased significantly. In contrast, A-C1 and A-C3 perform very differently. After 7 days, the corrosion rate of and corrosion risk sample A-C1 and A-C3 decreased gradually, and by 28 days, the corrosion rate and corrosion risk of sample $\mathrm{A}-\mathrm{C} 1$ and $\mathrm{A}-\mathrm{C} 3$ was lower than that of sample A0. Since, during the ECE process, a large number of hydrogen peroxide ions were generated by the cathode reaction, which can continuously reduce the chloride ion content around the reinforcement and decreased the corrosion rate and the corrosion risk of the rebar. 


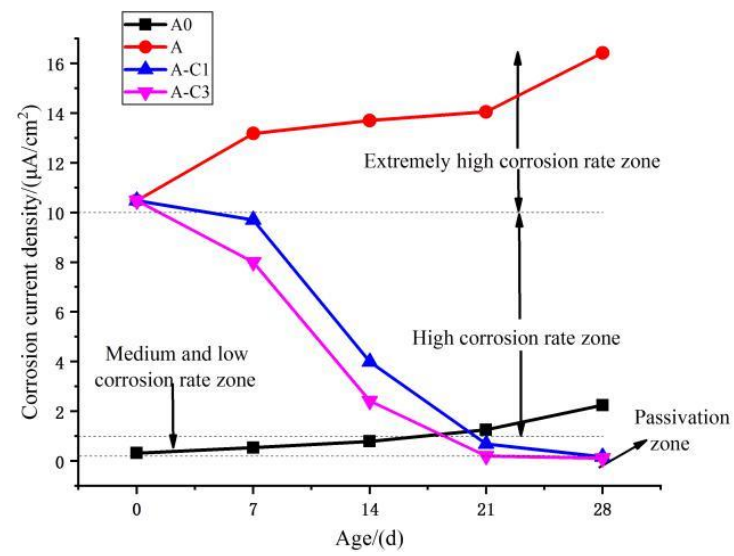

(a) Corrosion current of steel bar

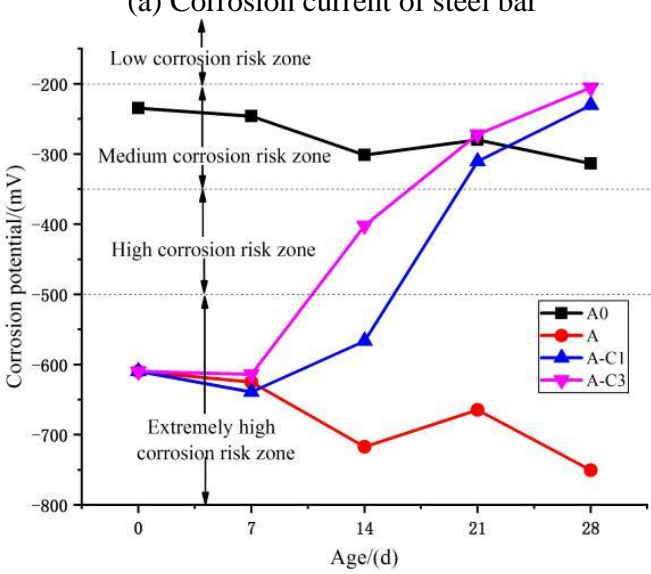

(b) Corrosion potential of steel bar

Figure 4. Corrosion current and corrosion potential of steel bar.

In the process of ECE, the efficiency of desalination is changed at different current densities. The corrosion rate of column A-C3 decreases faster, which shows that current density $3 \mathrm{~A} / \mathrm{m}^{2}$ can reduce the corrosion risk of steel bars faster, and the efficiency of dechlorination is higher. After ECE for 28 days, the corrosion current of column A-C1 and A-C3 decreased to $1.62 \%$ and $1.05 \%$ of the initial value respectively, and the corrosion risk was lower than that of column A0.

\section{Conclusions}

With MPC as binder, CFRP was bonded on the surface of reinforced concrete to form MPC-CFRP composite as the external anode of ECE. During ECE for 28 days, the polarization curves of steel bars were collected and analyzed every 7 days. The results show that the ECE system with MPC-CFRP as external anode has a good dechlorination effect. After 7 days of ECE, the corrosion rate of steel began to decrease rapidly; after 21 days of dechlorination, the corrosion rate of steel slowed down.

The current density of $1 \mathrm{~A} / \mathrm{m}^{2}$ and $3 \mathrm{~A} / \mathrm{m}^{2}$ are used for ECE respectively. The results show that the efficiency of ECE is not the same at different current densities, and the efficiency of dechlorination at $3 \mathrm{~A} / \mathrm{m}^{2}$ current density is higher than $1 \mathrm{~A} / \mathrm{m}^{2}$ current density; after sufficient desalting, the current density of $1 \mathrm{~A} / \mathrm{m}^{2}$ and $3 \mathrm{~A} / \mathrm{m}^{2}$ can both make the reinforcement passivate again.

\section{Acknowledgement}

The authors would like to acknowledge the financial support provided by National Natural Science Foundation of China (No.51678011)

\section{References}

1. J P Broomfield 1997 Corrosion of Steel in Concrete John Wiley \& Sons, Inc.

2. Soylev T A, R François (2003) Quality of steel-concrete interface and corrosion of reinforcing Steel, Cement \& Concrete Research 33(9):1407-1415

3. Ormellese M, Berra M, Bolzoni F, et al. (2006) Corrosion inhibitors for chlorides induced corrosion in reinforced concrete structures, Cement and Concrete Research 36(3):536-547

4. Shi X, Xie N, Fortune K, et al. (2012) Durability of steel reinforced concrete in chloride environments:An overview, Construction and Building Materials 30:125-138

5. Tritthart J (1998) Electrochemical chloride removal: an overview and scientific aspects, The American Ceramic Society 401-441

6. Carmona J, Climent M, et al. (2015) Shape Effect of Electrochemical Chloride Extraction in Structural Reinforced Concrete Elements Using a New Cement-Based Anodic System, Materials 8:2901-2917

7. Yeih W, Chang J, et al. (2016) Electrochemical chloride removal for reinforced concrete with steel rebar cage using auxiliary electrodes, Cement and Concrete Composites 74:136-146

8. Saraswathy V, Lee H, et al. (2018) Extraction of chloride from chloride contaminated concrete through electrochemical method using different anodes, Construction and Building Materials 158:549-562

9. Zhu J H, Wei L, Moahmoud H, et al. ( 2017 ) Investigation on CFRP as dual-functional material in chloride-contaminated solutions, Construction and Building Materials 151: 127-137

10. Sun H, Wei L, Zhu M, et al. (2016) Corrosion behavior of carbon fiber reinforced polymer anode in simulated impressed current cathodic protection system with $3 \% \mathrm{NaCl}$ solution, Construction and Building Materials 112: 538-546

11. Zhu J H, Wei L, Zhu M, et al. (2015) Polarization Induced Deterioration of Reinforced Concrete with CFRP Anode, Materials 8(7): 4316-4331 